Winarti, E. (2014). Study on related courses to help undergraduate students write research reports. Journal of Education and Learning. Vol. 8(1) pp. 85-90.

\title{
Study on Related Courses to Help Undergraduate Students Write Research Reports: A Curriculum Evaluation
}

\author{
Eny Winarti* \\ Department of Teacher Training of Elementary School \\ Sanata Dharma University, Yogyakarta, Indonesia
}

\begin{abstract}
Abstrak
Dari Pengalaman ketika menguji skripsi enam orang mahasiswa/i PGSD, mengajar mata kuliah metode penelitian dan Penelitin Tindakan Kelas (PTK), peneliti mengidentifikasi bahwa logika penelitian dan logika berbahasa menjadi kendala terbesar mahasiswa untuk menulis skripsi. Dari temuan tersebut, peneliti terdorong untuk mengidentifikasi matakuliah yang berpotensi memberikan kontribusi kepada mahasiswa dalam penulisan skripsi berikut materinya. Untuk mengidentifikasi, peneliti melakukan studi kepustakaan. Peneliti juga melakukan wawancara untuk mengidentifikasi kesesuaian antara silabus matakuliah dan pembelajaran di kelas. Wawancara ini melibatkan dosen pengampu mata kuliah dan mahasiswa/i peserta kuliah. Hasil penelitian menunjukkan bahwa matakuliah logika, menulis akademik, statistik, metodologi penelitian dan penelitian tindakan kelas adalah matakuliah yang mempunyai potensi untuk membantu mahasiswa menulis skripsi. Isi materi perkuliahan juga sudah cukup membantu. Akan tetapi, perlu studi lebih lanjut mengapa materi tersebut masih belum dapat dipahami dengan baik oleh mahasiswa.
\end{abstract}

Kata kunci: pendidikan, kurikulum, evaluasi, laporan penelitian, skripsi

\begin{abstract}
From the experience of joining the boards in the students' research report defence, teaching education research methodology, and classroom action research, the researcher indicated that students had challenges related with the logic of research methods and academic research writing. These findings encouraged the researcher to study the courses that have potential in helping students writing their research reports. To study the courses, the researcher analysed related documents, such as syllabi and lesson plans. The researcher also interviewed teachers and students to clarify the relevance of the syllabi and the classroom learning. The results of the study indicated that logic, academic writing, statistics, research methodology, and classroom action research had the potential of helping the students write their research report. The researcher also indicated that the content of the courses should have been more helpful. The fact, however, was that the students still had challenges understanding the materials after taking the courses. Further study about this fact is then recommended.
\end{abstract}

Keywords: education, curriculum, evaluation, research report, undergraduate writing

\footnotetext{
*Eny Winarti, S.Pd., M.Hum., Ph.D, Department of Teacher Training of Elementary School, Sanata Dharma University, Yogyakarta, Indonesia

E-mail: enywinarti@gmail.com
} 


\section{Introduction}

Based on the preliminary research in "Identifying the challenges of undergraduate students in writing research reports: A preliminary study" (Winarti, 2013), it is identified that in writing their research reports, the students had challenges in providing thorough background to the reader. Students especially found challenges in formulating research questions that were in line with the nature of their predetermined research topic. They also had difficulties in determining research theories that might contribute to their ability to answer the research questions. In addition, the students faced challenges in formulating research hypotheses and applying appropriate research methods.

The research particularly revealed that the students had challenges in using appropriate language mechanics. The students were especially lacking in consistently using a time line for narration. They also found difficulties in accurately describing their topics for discussion. Essentially, they could not determine whether they would use a bird-eye's point of view or spectator's point of view. They sometimes mixed them inconsistently. The students were also unaware that when they compared and contrasted different aspects, the topics being compared should be of the same categories or classes (Winarti, 2013). The other challenges that students faced involved basic reasoning skills and explaining consequential cause and effects. From those findings, it was recommended that courses that could intensively help the students deal with the challenges related to the logic of research and language mechanics were further needed.

This recommendation encourages the researcher to study the courses that have the potential for helping students to better write research reports. In order to identify the potential courses, the researcher assumes that a curriculum evaluation needs to be done. Some people might assume that the causes of the students' lack of writing ability are a result of the teaching and learning methods, possibly due to a lack in the teachers' abilities in conveying the materials, or the inappropriateness of the learning materials or even the students' inability to understand the learning materials. For curriculum researchers, the sources of the students' lack of writing abilities can be analysed primarily by first evaluating the curriculum. In this context, the researcher defines curriculum as a set of learning plans either inside or outside of the classroom, which are incorporated in the subjects that might contribute to the students' learning and development. This argument delineates the rationale for why the researcher decided to first evaluate the curriculum.

In order to determine the potential courses that could better contribute to preparing students to write research report writing, the researcher provided three questions. The first question is: "What courses have so far contributed in preparing the students to write research report writing?" The second question is: "What materials are discussed in the related courses?" The third question is: "What materials are not yet included in the related syllabus but needed in preparing the students to write their final projects?"

\section{Review of The Literature}

In order to answer the research questions, two topics are discussed in this section. The first is the role of research report writing in the selected department for this study, which is Elementary School Teacher Education [Pendidikan Guru Sekolah Dasar, PGSD] in a private university in Yogyakarta, and the second is the current theories of curriculum development, implementation and evaluation. Those two topics are discussed respectively in this section. The section about the role of research report writing in PGSD is mainly taken from the guidelines of research report writing in the selected program of study.

\section{The role of research report in PGSD}

In PGSD, research report writing is one of the requirements for the students in order to pass their undergraduate program. Totalling six credit hours, the content of the research report should reflect the students' points of view about a topic related to elementary school education. It is emphasized in the guidelines that the students can choose basic or applied research, where basic research involves developing a new theory, and applied research implements an existing theory. The program of study also permits the students to do classroom action research [Penelitian Tindakan Kelas, PTK].

To evaluate the research report writing, the program of study has developed a rubric. The contents of the rubric cover the format of abstracts, introduction, literature review, research methods, findings, conclusions and implications, and references, which should follow the current APA style. It is also stipulated that the abstracts that the students write should not exceed 250 words. The number of the 
references and timeframe are also considered in the rubric. The logic of conducting the research, which should closely follow the rubric, explicates the focus of the evaluation of the content of the research report.

\section{Curriculum development, implementation, and evaluation}

There are a number of different approaches to define a curriculum, such as the ones proposed by Oliva (2009), Saylor, Alexander and Lewis (1981), Taba (1962), and Tyler (1969). All of these different approaches, however, basically refer to six steps of curriculum development covering: analysing the students' needs, formulating learning objectives, identifying students, learning experiences, organizing learning experiences, and finally, implementation and learning evaluation.

In analysing the students' needs, the needs should be negotiated with the needs of the stakeholders, including the students' community (Oliva, 2009). After the needs are negotiated, the learning objectives are formulated explicitly (Oliva, 2009). These learning objectives are central to the curriculum contents (Oliva, 2009; Saylor, Alexander, \& Lewis, 1981; Taba, 1962; Tyler, 1969). These objectives become the reference to determine students' learning experiences (Oliva, 2009). They are the sources in which a curriculum developer might determine their teaching organization and methods, often simply called lesson plans (Goodlad \& Richter, 1966; Joyce, Weil \& Calhoun, 2009; Philips \& Soltis, 2009). Those plans are then implemented in the classroom (Oliva, 2009).

In its implementation, those plans might change depending on the context. Weade (1987) describes that while preparing what a teacher is about to teach, she/he plans the teaching. What she/he plans are called planned curriculum. The teacher might modify the curriculum that they have planned while they are in the classroom. The materials that the teachers delivered to the students are called delivered curriculum. It is possible that the delivered curriculum is in fact the materials that the students need to engage. This is called engaged curriculum. Meanwhile, this engaged curriculum might be only partly enacted since some others might be a review from previous learning. The curriculum that is enacted is called enacted curriculum. As in common learning events, not all curriculum contents are well received by the students. The curriculum that is received by the students is called the received curriculum. Meanwhile, it is possible that the received curriculum is measured, but it is also possible that the received curriculum is only partly measured. The curriculum that is measured is called the measured curriculum. The dynamics of the curriculum implementation is illustrated in the following figure:

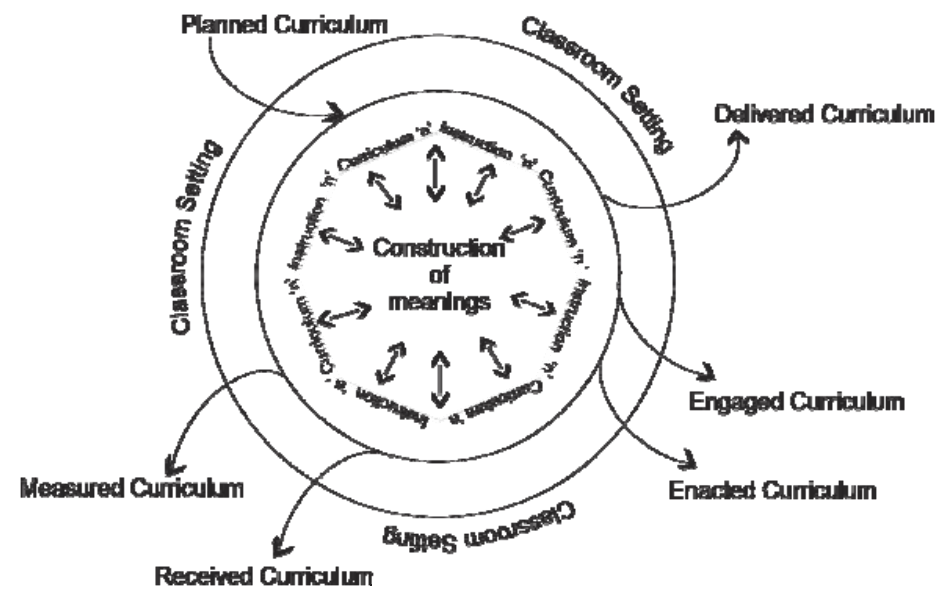

Figure 1. The cycle of curriculum and instructon. Reprinted from Weade, R. (1987).

Curriculum 'n Instruction, Theory Into Practice, 26(1), p. 16. 
The measured curriculum becomes the starting point for the learning measures. In the form of different types of learning measurements, the results of these measures become the learning feedback, which has the potential to contribute to curriculum revision and change (see Dick et al., 2005; English, 2010; Oliva, 2009). The results of the whole learning evaluation are used to determine whether or not a curriculum needs to be revised or only slightly adjusted (Dick et al., 2005; McNeil, 2006; Oliva, 2009).

\section{Research Methods}

To respond to the research questions, this study adopted qualitative methods focusing on curriculum evaluation. This research was conducted in a PGSD study program in a private university in Yogyakarta. Two sources of the data were involved in this study, namely documents and interviews. The documents included syllabi and lesson plans, and teachers' evaluations. The interviews involved the actual teachers and students. The interviews were designed to clarify data found in the documents.

In order to collect data, the researcher did library research to obtain the documents. The documents were then triangulated with the data gained from the interviews with the students and teachers. The main purpose of interviewing the teachers was to obtain further information about the documents, especially the ones related with the syllabus and the lesson plans. The main purpose of interviewing the students was to obtain further information related with the implementation of the syllabus and the lesson plans.

To analyse the data, the researcher first identified the possible courses that contribute to the students' preparation in writing research reports. This identification was based on the description of each course. This strategy served to answer the first research question. The findings were then used to determine what documents to study. Based on the study of the documents, the researcher then interviewed the teachers and students related with the documents. The data that resulted from the documents and interviews were then triangulated to answer the second and third research questions.

\section{Results}

The results of the study revealed that the description of each course in the program of study was not fully developed. Instead of obtaining the full description of each course from the guidelines in the program of study, the researcher needed to study the collected syllabi in the program of study. From the study of the syllabi, it was indicated that courses directly connected with the general research logic included logic, creative writing, statistics, research methods, and classroom action research. The courses indirectly connected with the general research logic were courses related with education professions such as curriculum and learning development, learning evaluation, child development, children with special needs, and other related subjects. These courses were considered less significant in contributing to students' research report writing skills considering that the basis of these courses might involve knowledge different from the specific topics of the students' research.

Based on the syllabi and the interviews, it was indicated that in logic, the teachers had challenges in detailing abstract concepts. The teachers struggled in helping the students make sense of the basic concepts of cause and effect, and conditionals. The causes of the students' failure in making sense of the concepts, however, need to be studied further. The students' challenges in studying statistics were related with the time allocation for the materials. In a semester, the students were supposed to study both descriptive and inferential statistics. The students' background in math, however, seemed insufficient to understand basic statistical concepts including percentages, and standard deviation. Consequently, the teachers often needed to review these basic concepts of statistics before she/he could move on to the next related concepts. The students had the tendency to memorize the formulas without understanding the meaning behind them. Meanwhile, the time constraints did not allow teachers to advance to the more advanced materials that are required for writing research projects. In some cases, until the end of the semester, the teachers could only cover the basic descriptive statistics. 
Unlike the nature of the two courses mentioned previously, in creative writing, the students were not exposed to learning materials, which were close enough in language mechanics to directly prepare them for writing research reports. Instead of introducing the students with the writing skills to narrate, describe, compare, classify, explain cause and effect, and develop argumentation, the courses contained beginning writing skills, such as paraphrasing, and summarising. The results of the interviews, however, revealed that even in the minor writing skills, the students still had major challenges. It was indicated that the students particularly lacked the ability to select what to include in summarizing.

Another challenge for the students involved the actual research methods. The program of study predetermined that the choice of research methods included both quantitative and qualitative approaches but due to limited time, they were not thoroughly introduced. However, similar to the challenges in learning of logic and statistics, the time constraints and the background knowledge of the students became the hindrance for the students to thoroughly practice doing research. Specifically, the lack of logical and statistical knowledge became a significant obstacle for the students to do quantitative research thoroughly and effectively. Meanwhile, the lack of the students' abilities in language mechanics and vocabulary became the challenge for the students to thoroughly develop their qualitative research. As well-known and well-established, qualitative research requires the use of an extensive vocabulary so that the researchers can produce a detailed and thorough description in the study.

\section{Conclusions}

Overall, the results of the study indicated that in general, courses in the program of study had the potential to prepare students in writing their research reports either in major or minor ways. The syllabus, the learning materials and the teaching and learning practice, however, needed further study so that the materials offered to students could more effectively and efficiently help the students write their research reports. Basically, the materials in the courses were generally well arranged. However, the time constraints and the students' background knowledge were of significant concern.

\section{Acknowledgement}

My gratitude goes to the Research and Service Institute of Sanata Dharma for the funding. Their encouragement and support has made this study happen.

\section{References}

Brandt, R. S., \& Tyler, R. W. (1983). Goals and objectives. In F. W. English (Ed.), Fundamental Curriculum Decisions (pp. 40-52). Alexandria, VA: Association for Supervision and Curriculum Development.

Dick, W., Carey, L., \& Carey, J. (2005). The systematic design of instruction . Boston: Pearson/Allyn and Bacon.

English, F. W. (2010). Deciding what to teach and test: Developing, aligning, and leading the curriculum ( $3^{\text {rd }}$ ed.)., CA: Corwin.

Goodlad, J. I., \& Richter, M. N., (1966). The development of a conceptual system for dealing with problems of curriculum and instruction (Contract No. SAE - 8024).

Jones, M., Jones, B. D., \& Hargrove, T. Y. (2003). The unintended consequences of high-stakes testing. MD: Rowman and Littlefield.

Joyce, B., Marsha, W., \& Calhoun, E. (2009). Models of teaching (8th ed.). MA: Allyn and Bacon. 
Mc.Neil, J. D. (2006). Contemporary curriculum: In thought and action (6th ed.). MA: John Weley \& Sons.

Oliva, P. F. (2009). Developing the curriculum (7 $7^{\text {th }}$ ed.). Boston, MA: Pearson Education.

Phillips, D. C. and Soltis, J. S. (2009). Perspectives on learning (5th ed.). NY: Teachers College.

Program Studi Pendidikan Guru Sekolah Dasar, Universitas Sanata Dharma. (2012) Pedoman Skripsi. Unpublished.

Saylor, J. G. Alexander In. M., Lewis, A. J. (1981). Curriculum planning for better Teaching and Learning. ( $4^{\text {th }}$ ed.). New York: Rinehart and Winston World Book Company.

Taba, H. (1962). Curriculum development: Theory and practice. NY: Harcourt Brace Jovanovich.

Tanner, D. \& Tanner, L. N., (1980). Curriculum development: Theory into practice. New York: Macmillan.

Tyler. R. W. (1969). Basic principles of curriculum and instruction.IL: University of Chicago.

Winarti, E. (2013). Identifying the challenges of undergraduate students in writing research projects: A preliminary study. International Conference in Educational Research and Innovation (ICERI). Yogyakarta: Yogyakarta State University.

Weade, R. (1987). Curriculum 'n Instruction, Theory Into Practice, 26(1). 